\title{
KARAKTERISTIK FOSFAT, NITRAT DAN OKSIGEN TERLARUT DI PERAIRAN SELAT LEMBEH, SULAWESI UTARA
}

\author{
(Characteristics of Phosphate, Nitrate and Dissolved Oxygen \\ in Lembeh Strait Waters, North Sulawesi)
}

\begin{abstract}
Simon I. Patty
UPT. Loka Konservasi Biota Laut Bitung-LIPI

e-mail : pattysimon@ymail.com

Research on the characteristics of phosphate, nitrate and dissolved oxygen have been carried out in Lembeh Strait waters, North Sulawesi in July 2013. The purpose of this study was to examine the characteristics and distribution of phosphate, nitrate and dissolved oxygen in Lembeh Strait waters. Phosphate and nitrate were analyzed using spectrophotometric method, while dissolved oxygen was determined with electrochemical method. Results of statistical analysis using t-test showed that the levels of phosphate and nitrate in the surface layer and near the bottom is significantly different. Dissolved oxygen levels were not significantly different between the surface layer and near the bottom. The different concentration of phosphate, nitrate and dissolved oxygen in Lembeh Strait waters were influenced by currents, water mass movement, phytoplankton activity and freshwater influx from the mainland. The levels of phosphate, nitrate and dissolved oxygen in the waters of the Strait of Lembeh is still relatively normal and desirable for marine life.
\end{abstract}

Keywords: Phosphate, Nitrate, Dissolved oxygen,Ccharacteristics, Lembeh Strait

Penelitian tentang karakteristik fosfat, nitrat dan oksigen terlarut telah dilaksanakan di perairan Selat Lembeh, Sulawesi Utara Juli 2013. Tujuan penelitian ini untuk mengkaji karakteristik dan sebaran fosfat, nitrat dan oksigen terlarut di perairan Selat Lembeh. Fosfat dan nitrat dianalisa dengan menggunakan metode spektrofotometri, sedangkan oksigen terlarut ditentukan dengan metoda elektrokimia. Hasil analisis statistik dengan menggunakan uji-t menunjukkan bahwa kadar fosfat dan nitrat di lapisan permukaan dengan dekat dasar adalah berbeda nyata. Kadar oksigen terlarut tidak berbeda nyata antara lapisan permukaan dengan dekat dasar. Tinggi rendahnya kosentrasi fosfat, nitrat dan oksigen terlarut di perairan Selat Lembeh dipengaruhi oleh arus, pergerakan massa air, aktifitas plankton dan masukkan dari daratan. Kadar fosfat, nitrat dan oksigen terlarut di perairan Selat Lembeh masih tergolong normal dan baik untuk kehidupan biota laut.

Kata kunci: Fosfat, Nitrat, Oksigen terlarut, Karakteristik, Selat Lembeh

\section{PENDAHULUAN}

Selat Lembeh merupakan wilayah perairan sempit dan memanjang yang memisahkan daratan utama Pulau Sulawesi dengan Pulau Lembeh. Secara geografi terletak diantara $1^{\circ} 23^{\prime}$ -

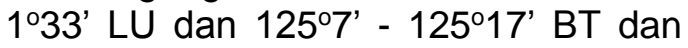
secara administratif masuk dalam wilayah kota Bitung, Sulawesi Utara. Perairan Selat Lembeh berada di antara laut Maluku yang dipengaruhi oleh massa air dari lautan Pasifik dan laut
Sulawesi dipengaruhi oleh massa air dari lautan Hindia. Karena letaknya di daerah indo-pasifik tropis, maka kawasan pesisir dan laut di perairan ini memiliki keanekaragaman hayati (biodiversity) yang sangat tinggi. Padang lamun yang cukup luas berserta keanekaragaman biota laut yang hidup di dalamnya, disamping potensi terumbu karang berserta keanekaragaman biotanya menyebabkan berkembangnya kegiatan wisata bahari di perairan ini. Tidak mengherankan bila Selat Lembeh 
juga dijadikan sebagai destinasi wisata bahari bagi masyarakat Bitung bahkan bagi wisatawan mancanegara.

Selat Lembeh termasuk wilayah perairan yang strategis, merupakan jalur pelayaran masuk keluarnya kapal lokal maupun kapal asing yang akan berlabuh di pelabuhan Samudera Bitung. Wilayah ini nampak semakin meningkat perannya sejalan dengan pembangunan di Kota Bitung. Jumlah penduduk di sekitar perairan pantai semakin padat dengan segala aktivitas perekonomiannya, transportasi laut juga semakin meningkat dengan dibangunnya sebuah pelabuhan peti emas. Selain itu terdapat beberapa jenis industri di pesisir pantai, seperti industri percetakan, pengalengan ikan, pabrik peleburan seng, galangan kapal dan lain-lain. Berbagai aktivitas yang dilakukan di wilayah Selat Lembeh akan berpotensi memberikan perubahan kondisi perairan baik meliputi sifat fisika, kimia maupun biologi perairan yang pada akhirnya akan menurunkan fungsi ekologis terhadap ekosistem yang ada di perairan ini.

Keberadaan ekosistem yang kompleks dan berbagai aktivitas di wilayah perairan tersebut yang tidak terkontrol mempunyai pengaruh terhadap kandungan fosfat, nitrat dan oksigen terlarut. Kandungan fosfat dan nitrat secara alamiah berasal dari perairan itu sendiri yaitu melalui prosesproses penguraian, pelapukan ataupun dekomposisi tumbuh-tumbuhan dan sisa-sisa organisme mati. Selain itu juga tergantung pada keadaan sekeliling diantaranya sumbangan dari daratan melalui sungai yang bermuara ke perairan, seperti buangan limbah ataupun sisa pakan dengan adanya bakteri terurai menjadi zat hara (Wattayakorn, 1988), dan dalam proses penguraiannya banyak membutuhkan oksigen. Oksigen terlarut dalam air berasal dari hasil proses fotosintesis oleh fitoplankton atau tanaman air lainnya dan difusi dari udara (Bhatt dalam Andriani, 1999). Fosfat, nitrat dan oksigen terlarut merupakan tiga unsur senyawa kimia yang sangat penting untuk mendukung kehidupan organisme dalam suatu perairan. Fosfat dan nitrat dibutuhkan untuk mendukung organisme dalam pertumbuhan dan perkembangan hidupnya terutama fitoplankton, sedangkan oksigen terlarut digunakan oleh organisme perairan dalam proses respirasi. Secara alami ketiga senyawa kimia ini terdapat dalam air laut pada kadar yang sesuai. Perubahan kadar yang terjadi tentu akan mempengaruhi kehidupan organisme yang hidup dalam perairan. Tulisan ini akan menguraikan tentang karakteristik zat hara (fosfat, nitrat) dan oksigen terlarut di perairan Selat Lembeh.

\section{METODE PENELITIAN}

Penelitian dilaksanakan di perairan Selat Lembeh pada bulan Juli 2013. Sampel air laut diambil dengan menggunakan tabung nansen sebanyak 8 stasiun pada lapisan permukaan dan dekat dasar. Penentuan posisi masingmasing stasiun penelitian dilakukan dengan menggunakan Garmin handportable GPS Map 60 CSx, disajikan dalam Gambar 1.

Kadar fosfat dan nitrat dianalisa menurut metode spektrofotometri dengan menggunakan alat spektrofotometer 'Nicolet Evolution 100' seperti yang diterangkan dalam APHA, AWWA, WEF (2005), dan nilainya

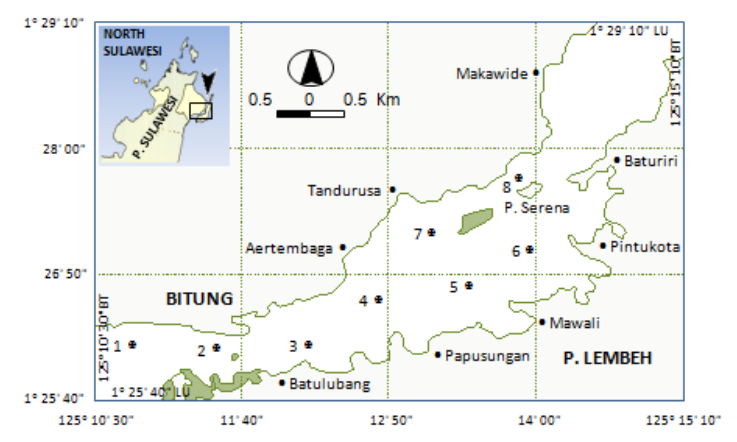

Gambar 1. Stasiun penelitian di perairan Selat Lembeh.

dinyatakan dalam $\mathrm{mg} / \mathrm{l}$. Pengukuran kadar oksigen terlarut ditentukan dengan metoda elektrokimia 
menggunakan alat DO meter AZ 8563 dan nilainya dinyatakan dalam ppm. Data fosfat, nitrat dan oksigen terlarut disajikan dalam bentuk peta sebaran dengan perangkat lunak ArcView 3.3 dan Golden Software Surfer versi 8 serta analisa statistik dengan menggunakan SPSS 16.

\section{HASIL DAN PEMBAHASAN}

Hasil pengukuran kadar fosfat, nitrat, dan oksigen terlarut di perairan Selat Lembeh disajikan dalam Tabel 1, serta hasil analisa uji-t untuk mengetahui ada tidaknya perbedaan antara kondisi perairan di lapisan permukaan dan dekat dasar dari ketiga parameter disajikan pada Tabel 2.

\section{Fosfat}

Hasil pengamatan menunjukkan bahwa kadar fosfat di lapisan permukaan perairan Selat Lembeh

Tabel 1. Kosentrasi Fosfat, Nitrat dan Oksigen Terlarut di Perairan Selat Lembeh

\begin{tabular}{c|c|c|c|c|c|c|}
\hline \multirow{2}{*}{ Kosentrasi } & \multicolumn{3}{|c|}{ Permukaan $(0 \mathrm{~m})$} & \multicolumn{2}{c|}{ Dekat Dasar $(25-30 \mathrm{~m})$} \\
\cline { 2 - 7 } & $\begin{array}{c}\mathrm{PO}_{4} \\
(\mathrm{mg} / \mathrm{l})\end{array}$ & $\begin{array}{c}\mathrm{NO}_{3} \\
(\mathrm{mg} / \mathrm{l})\end{array}$ & $\begin{array}{c}\mathrm{O}_{2} \\
(\mathrm{ppm})\end{array}$ & $\begin{array}{c}\mathrm{PO}_{4} \\
(\mathrm{mg} / \mathrm{l})\end{array}$ & $\begin{array}{c}\mathrm{NO}_{3} \\
(\mathrm{mg} / \mathrm{l})\end{array}$ & $\begin{array}{c}\mathrm{O}_{2} \\
(\mathrm{ppm})\end{array}$ \\
\hline Minimun & 0,005 & 0,015 & 4,64 & 0,007 & 0,024 & 4,58 \\
\hline Maksimum & 0,011 & 0,026 & 5,85 & 0,015 & 0,035 & 5,59 \\
\hline Rata-rata & 0,008 & 0,02 & 5,28 & 0,011 & 0,03 & 5,2 \\
\hline Standar Deviasi & 0,002 & 0,003 & 0,39 & 0,003 & 0,003 & 0,33 \\
\hline
\end{tabular}

Tabel 2. Analisis Uji-t terhadap Fosfat, Nitrat dan Oksigen Terlarut

\begin{tabular}{|c|c|c|c|c|c|}
\hline \multirow{2}{*}{ Parameter } & \multirow{2}{*}{$\begin{array}{l}\text { Sig. (2- } \\
\text { tailed) }\end{array}$} & \multirow{2}{*}{ t-hit } & \multirow{2}{*}{$\mathrm{df}$} & \multicolumn{2}{|c|}{ t-tab } \\
\hline & & & & $5 \%$ & $1 \%$ \\
\hline $\begin{array}{c}\text { Fosfat } \\
\text { permukaan- } \\
\text { dekat dasar }\end{array}$ & 0,009 & $3,594^{*}$ & 7 & 2,365 & 3,499 \\
\hline $\begin{array}{c}\text { Nitrat } \\
\text { permukaan- } \\
\text { dekat dasar }\end{array}$ & 0 & $8,428^{\star *}$ & 7 & 2,365 & 3,499 \\
\hline $\begin{array}{c}\text { Oksigen } \\
\text { permukaan- } \\
\text { dekat dasar }\end{array}$ & 0,351 & 0,999 & 7 & 2,365 & 3,499 \\
\hline
\end{tabular}
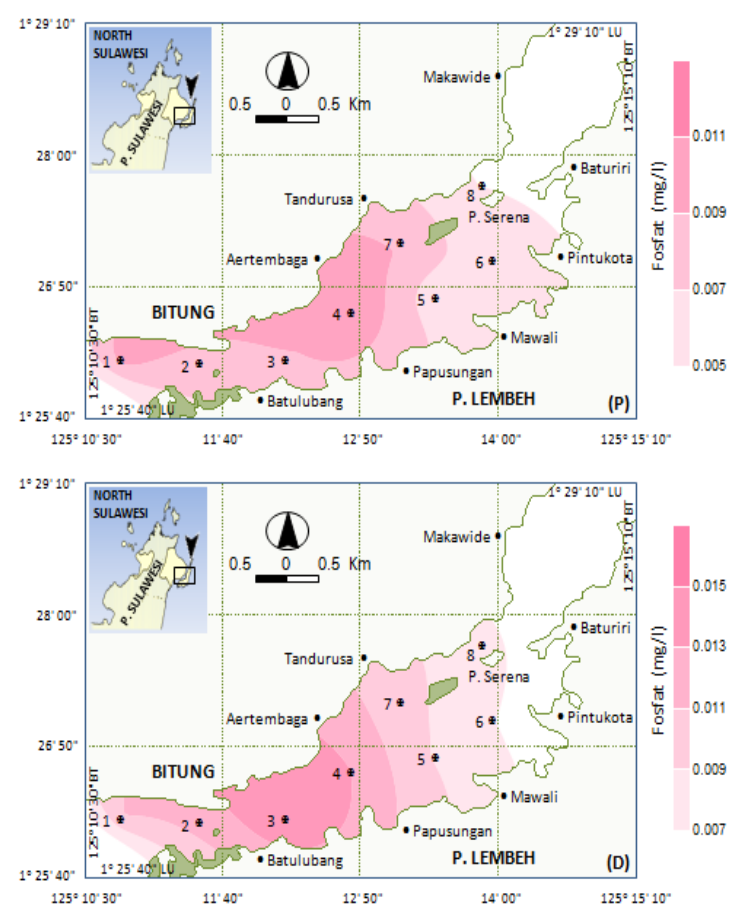

Gambar 2. Sebaran horizontal fosfat (mg/l) permukaan $(\mathrm{P})$ dan dekat dasar (D) di perairan Selat lembeh, Juli 2013.

berkisar antara 0,005-0,011 $\mathrm{mg} / \mathrm{l}$, dengan rata-rata $0,008 \pm 0,002 \mathrm{mg} / \mathrm{l}$ dan dekat dasar berkisar antara 0,007-0,015 $\mathrm{mg} / \mathrm{l}$, dengan rata-rata $0,011 \pm 0,003$ $\mathrm{mg} / \mathrm{l}$. Dari data tersebut terlihat bahwa kosentrasi fosfat permukaan dan dekat dasar berbeda, dimana rata-rata kadar fosfat dekat dasar lebih tinggi dibandingkan di lapisan permukaan. Tingginya kadar fosfat di dasar perairan karena dasar perairan umumnya kaya akan zat hara, baik yang berasal dari dekomposisi sedimen maupun senyawa-senyawa organik yang berasal dari jasad flora dan fauna yang mati (Edward dan Tarigan, 2003). Kondisi ini sesuai dengan pendapat Muchtar dan Simanjuntak (2008) bahwa secara alamiah fosfat terdistribusi mulai dari permukaan sampai dasar. Semakin ke dasar semakin tinggi konsentrasinya sebagai akibat dari dasar laut yang kaya akan nutrisi dan konsentrasinya semakin rendah semakin jauh ke arah laut. Rendahnya kadar fosfat di lapisan permukaan kemungkinan dapat pula 
disebabkan oleh aktifitas fitoplankton yang intensif.

Hasil analisis statistik dengan menggunakan uji-t menunjukkan bahwa terdapat perbedaan antara kadar fosfat di lapisan permukaan dengan fosfat di lapisan dekat dasar (t-hit > t-tab). Kosentrasi fosfat lapisan permukaan maupun dekat dasar dengan kadar terendah dijumpai di stasiun 8 dan stasiun 6, sedangkan kadar fosfat tertinggi terdapat di stasiun 4 dan stasiun 3 (Gambar 2). Konsentrasi fosfat dengan kadar tertinggi mendominasi perairan bagian barat daya dan mendekat ke arah pantai, sedangkan fosfat dengan kadar terendah sebarannya menjauh menuju ke arah timur laut (P. Serena).

Secara keseluruhan kadar fosfat di perairan Selat Lembeh berkisar antara $0,005-0,015 \mathrm{mg} / \mathrm{l}$ dengan ratarata $0,009 \mathrm{mg} / \mathrm{l}$, sesuai dengan kadar fosfat yang dijumpai di perairan laut yang normal umumnya. Kadar fosfat di perairan laut yang normal berkisar antara 0,01-4 $\mu$ g.at/l atau setara dengan 0,00031-0,124 $\mathrm{mg} / \mathrm{l}$ (Brotowidjoyo dalam Edward dan Tarigan, 2003). Kadar fosfat di perairan ini masih berada di batasan konsentrasi yang dipersyaratkan Disebutkan bahwa baku mutu konsentrasi fosfat yang layak untuk kehidupan biota laut dalam keputusan Menteri Lingkungan Hidup, $\mathrm{KLH}$ (2004) adalah 0,015 mg/l. Ketchum (1969) menetapkan suatu nilai fosfat sebesar $2,8 \mu \mathrm{g}$.at/l atau setara dengan $0,087 \mathrm{mg} / \mathrm{l}$ sebagai batas atas pada air yang tidak tercemar.

\section{Nitrat}

Kadar nitrat lapisan permukaan dan dekat dasar yang diperoleh di perairan Selat Lembeh menunjukkan perbedaan yang signifikan. Kadar nitrat lapisan permukaan berkisar antara 0,015-0,026 $\mathrm{mg} / \mathrm{l}$ dengan nilai rata-rata $0,020 \pm 0,003 \mathrm{mg} / \mathrm{l}$, sedangkan kadar nitrat di dekat dasar berkisar antara 0,024-0,035 $\mathrm{mg} / \mathrm{l}$ dengan nilai rata-rata $0,030 \pm 0,003 \mathrm{mg} / \mathrm{l}$. Konsentrasi nitrat rata-rata lebih tinggi di dekat dasar perairan dibanding dengan di lapisan permukaan. Perbedaan rata-rata kadar nitrat antara kedua lapisan kedalaman cukup besar yaitu $0,011 \mathrm{mg} / \mathrm{l}$. Hal ini disebabkan karena nitrat di lapisan permukaan lebih banyak dimanfaatkan oleh fitoplankton. Selain itu, konsentrasi nitrat yang lebih tinggi di dekat dasar perairan juga dipengaruhi oleh sedimen. Di dalam sedimen nitrat diproduksi dari biodegradasi bahan-bahan organik menjadi ammonia yang selanjutnya dioksidasi menjadi nitrat (Seitzinger, 1988). Fenomena ini diperkuat oleh hasil analisis statistik dengan menggunakan uji-t yang menunjukkan bahwa terdapat perbedaan sangat nyata (t-hit > t-tab) antara kadar nitrat di lapisan permukaan dengan nitrat di dekat dasar (Tabel 2).

Adanya kandungan nitrat yang rendah dan tinggi pada kondisi tertentu dapat disebabkan oleh berbagai faktor, antara lain adanya arus yang

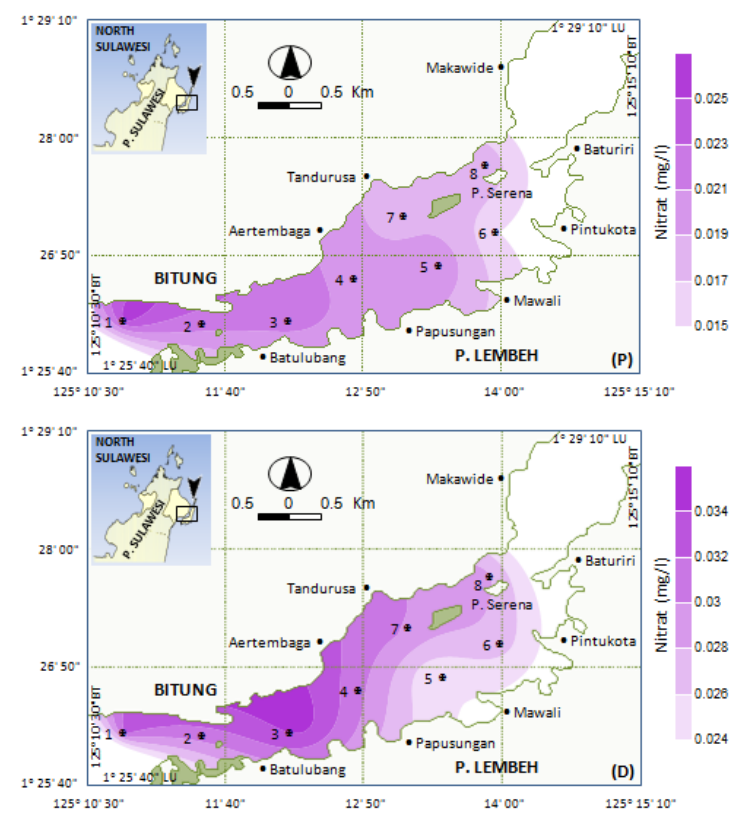

Gambar 3. Sebaran horizontal nitrat (mg/l) permukaan (P) dan dekat dasar (D) di perairan Selat lembeh, Juli 2013. 
membawa nitrat dan kelimpahan fitoplankton (Koesoebiono, 1981). Kadar nitrat terendah lapisan permukaan terdapat di stasiun 6 dan tertinggi di stasiun 1. Sedangkan konsentrasi nitrat dekat dasar, kadar terendah dijumpai di stasiun 5 dan tertinggi di stasiun 3 (Gambar 3). Kosentrasi nitrat permukaan maupun dekat dasar dengan kadar tertinggi sebarannya mendekat ke arah pantai bagian barat daya perairan ini dan kadar terendah penyebarannya menjauh menuju ke arah timur laut. Kondisi ini diperkuat oleh pendapat Hutagalung dan Rozak (1997) menyatakan bahwa kadar nitrat semakin tinggi bila kedalaman bertambah, sedangkan untuk sebaran horizontal kadar nitrat semakin tinggi menuju ke arah pantai.

Kadar nitrat perairan Selat Lembeh secara keseluruhan berkisar antara 0,015-0,035 mg/l dengan ratarata $0,025 \mathrm{mg} / \mathrm{l}$, masih diatas kandungan nitrat yang umum dijumpai di perairan laut. Kandungan nitrat yang normal di perairan laut umumnya berkisar antara 0,01-50 $\mu \mathrm{g}$.at/l atau setara dengan 0,00014-0,7 mg/l (Brotowidjoyo dalam Edward dan Tarigan, 2003). Nilai ambang batas suatu perairan yang ditetapkan US-EPA (1973) untuk nitrat sebesar 0,07 mg/l. KLH (2004) menetapkan standar baku mutu senyawa nitrat untuk biota laut sebesar 0,008 mg/l. Chu dalam Wardoyo (1982) mengemukakan bahwa kisaran kadar nitrat 0,3-0,9 mg/l cukup untuk pertumbuhan organisme dan $>3,5$ $\mathrm{mg} / \mathrm{l}$ dapat membahayakan perairan. Sedangkan Effendi dalam Simanjuntak (2012) menyatakan kadar nitrat perairan $>0,2 \mathrm{mg} / \mathrm{l}$ dapat mengakibatkan terjadinya eutrofikasi yang dapat merangsang pertumbuhan fitoplankton dengan cepat (blooming). Bila ditinjau dari kadar nitrat yang merupakan salah satu indikator kesuburan, maka kisaran kadar nitrat di perairan Selat Lembeh masih dalam batas aman kesuburan suatu perairan.
Kadar oksigen terlarut di lapisan permukaan perairan Selat Lembeh berkisar antara 4,64-5,85 ppm dengan rata-rata 5,28 $\pm 0,39 \mathrm{ppm}$ dan dekat dasar berkisar antara 4,58-5,59 ppm dengan rata-rata 5,20 $\pm 0,33$ ppm. Kadar oksigen terlarut di perairan ini relatif lebih rendah bila dibandingkan dengan kadar oksigen terlarut yang dijkumpai di perairan laut umumnya. Kadar oksigen di perairan laut yang normal berkisar antara 5,7-8,5 ppm (Sutamihardja, 1987). Rendahnya kandungan oksigen di perairan ini diduga karena masuknya bahan-bahan organik ke perairan, sehingga memerlukan banyak oksigen untuk menguraikannya. Semakin banyak bahan buangan organik yang ada di dalam air, semakin sedikit sisa kandungan oksigen yang terlarut di dalamnya. Menurut Klein dalam Andriani (1999) bahwa kadar oksigen terlarut dalam suatu perairan akan menurun akibat proses pembusukkan bahan organik, respirasi, dan reaerasi terhambat.

Secara umum tidak ada perbedaan yang nyata antara kandungan oksigen terlarut di lapisan permukaan dengan di dekat dasar (t-hit $<$ t-tab). Kosentrasi oksigen terlarut terendah di lapisan permukaan maupun dekat dasar dijumpai di stasiun 3 dan stasiun 2, sedangkan kadar tertinggi terdapat di stasiun 6 dan stasiun 8 . Kosentrasi oksigen terlarut dengan kadar tertinggi mendominasi perairan bagian timur laut dan kadar oksigen terendah sebarannya mendominasi perairan barat daya (Gambar 4). Dari Gambar 4, terlihat konsentrasi oksigen terlarut permukaan maupun dekat dasar yang mendekat ke pantai kadarnya semakin tinggi dan ke arah laut semakin rendah. Hal ini mungkin disebabkan karena kebutuhan oksigen terlarut untuk proses respirasi oleh mikroorganisme dalam jumlahnya banyak. Menurut Nybakken (1988), bahwa secara horizontal diketahui oksigen terlarut semakin ke arah laut

\section{Oksigen Terlarut}




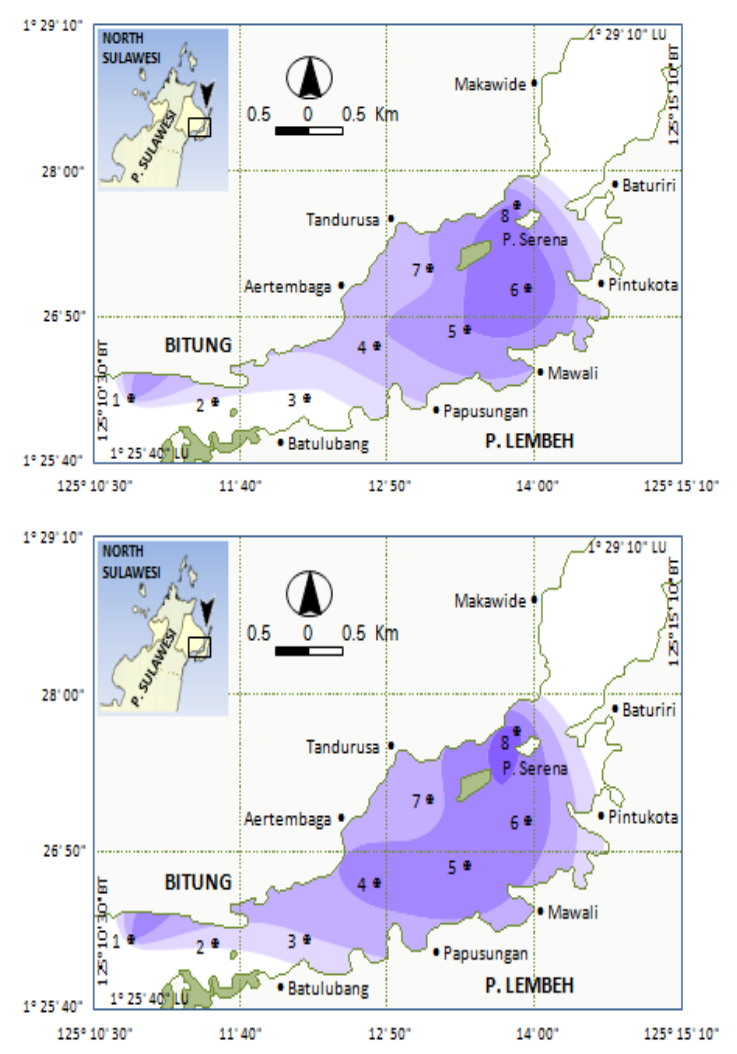

Gambar 4. Sebaran horizontal oksigen terlarut (ppm) permukaan $(P)$ dan dekat dasar (D) di perairan Selat lembeh, Juli 2013.

maka kadar oksigen terlarut akan semakin menurun juga. Tinggi rendahnya kardar oksigen di daerah ini, erat kaitannya dengan kekeruhan air laut dan aktifitas mikro-organisme untuk semakin menurun juga. Tinggi rendahnya kardar oksigen di daerah ini, erat kaitannya dengan kekeruhan air laut dan aktifitas mikro-organisme untuk menguraikan zat organik menjadi zat anorganik yang menggunakan oksigen terlarut (bioproses).

Kadar oksigen terlarut yang diperoleh di perairan Selat Lembeh, secara keseluruhan berkisar antara 4,54-5,85 ppm dengan rata-rata 5,24 ppm, masih berada dibatasan konsentrasi yang dipersyaratkan. KLH, (2004) menetapkan nilai ambang batas oksigen terlarut untuk kehidupan biota laut adalah $\geq 5 \mathrm{ppm}$. Kadar oksigen terlarut di perairan ini termasuk pada kategori tercemar ringan, kadar oksigen di perairan laut yang tercemar ringan adalah 5 ppm (Sutamihardja, 1987). Kadar oksigen terlarut di dalam massa air nilainya adalah relatif, biasanya berkisar antara 6-14 ppm (Connel \& Miller, 1995). Menurut Da'i (1991), kadar oksigen di Teluk Nanwan, Taiwan dimana terumbu karang tumbuh dan berkembang dengan baik berkisar antara 4,27-7,14 ppm. Rivai (1983) mengatakan bahwa pada umumnya kandungan oksigen sebesar 5 ppm dengan suhu air berkisar antara 20-30 ${ }^{\circ} \mathrm{C}$ relatif masih baik untuk kehidupan ikan-ikan, bahkan apabila dalam perairan tidak terdapat senyawasenyawa yang bersifat toksik (tidak tercemar) kandungan oksigen sebesar 2 ppm sudah cukup untuk mendukung kehidupan organisme perairan (Swingle dalam Salmin, 2005).

\section{KESIMPULAN}

Kadar fosfat, nitrat dan oksigen terlarut di perairan Selat Lembeh masih dalam kondisi normal untuk kategori perairan pantai dan masih baik untuk kehidupan biota laut. Kadar fosfat dan nitrat di lapisan permukaan dengan di dekat dasar adalah berbeda nyata, sedangkan kadar oksigen terlarut tidak menunjukkan perbedaan yang nyata. Kadar fosfat, nitrat dan oksigen terlarut di perairan Selat Lembeh dipengaruhi oleh arus, pergerakan massa air, aktifitas plankton dan masukkan dari daratan.

\section{DAFTAR PUSTAKA}

Andriani, E.D. 1999. Kondisi Fisika-Kimiawi Air Perairan Pantai Sekitar Tambak Balai Budidaya Air Payau (BBAP) Jepara, Kabupaten Jepara, Jawa Tengah. Skripsi. Fakultas Perikanan dan Ilmu Kelautan, Institut Pertanian Bogor.

APHA, AWWA, WEF. 2005. Standard Method for the Examination of Water and Wastewater, edition 21:4-153. 
Connel, W.D., Miller, G.J. 1995. Kimia dan Ekotoksikologi Pencemaran. Terjemahan, Penerbit Universitas Indonesia. 520 hal.

Dai, C.F. 1991. Reef Environment and Coral Fauna of Southern Taiwan. Atoll Resources Bulletin 354:1.

Edward, Tarigan, M.S. 2003, Pengaruh Musim Terhadap Fluktuasi Kandungan Fosfat dan Nitrat di Laut Banda. Makara Sains, Vol. 7(2): 8289.

Edward, Tarigan, Z. 2003. Pemantauan Kondisi Hidrologi di Perairan Raha P. Muna, Sulawesi Tenggara dalam Kaitannya dengan Kondisi Terumbu Karang. Makara, Sains. Vol. 7(2):73-82.

Hutagalung, H.P., Rozak, A.. 1997. Metode Analisis Air Laut, Sedimen dan Biota. Buku 2. Pusat Penelitian dan Pengembangan Oseanologi LIPI, Jakarta.

Koesoebiono. 1981. Plankton dan Produktivitas Bahari. Fakultas Perikanan-Institut Pertanian Bogor, Bogor.

Menteri Negara KLH. 2004. Keputusan Menteri Negara Lingkungan Hidup No. 51 Tahun 2004 Tentang Baku Mutu Air Laut Untuk Biota Laut. Jakarta.

Muchtar, M., Simanjuntak. 2008, Karakteristik dan Fluktuasi Zat Hara Fosfat, Nitrat dan Derajat Keasaman $(\mathrm{pH})$ di estuary Cisadane pada Musim yang Berbeda. Dalam: Ruyitno, A., Syahailatua, M., Muchtar, Pramudji, Sulistijo, Susana, T. (Editor). Ekosistem Estuari Cisadane: LIPI: 139-148.

Nybakken, J.W. 1998. Biologi Laut Suatu Pendekatan Ekologi. Penerjemah: Eidman, M., Koesoebiono, Bengen, D.G., Hutomo, M., Sukarjo,S.. PT. Gramedia. Jakarta. 459 hal.

Riva'i, R.S., Pertagunawan, K., 1983. Biologi Perikanan I. Penerbit CV. Kayago, Jakarta. 143 hal
Salmin. 2005. Oksigen Terlarut (DO) dan Kebutuhan Oksigen Biologi (BOD) sebagai Salah Satu Indikator untuk Menentukan Kualitas Perairan. Oseana Vol.XXX (3): 21 - 26.

Seitzinger, S.P. 1988. Denitrification in freshwater and marine coastal ecosystems: Ecological and geochemical significance. Limnol. Oceanogr. 33 (4, Part 2): 702-724.

Simanjuntak, M. 2012. Kualitas Air Laut Ditinjau dari Aspek Zat Hara, Oksigen Terlarut dan pH di Perairan Banggai, Sulawesi Tengah. Jurnal IImu dan Teknologi Kelautan Tropis FPIK-IPB. Vol. 4, No. 2:290-303.

Sutamiharja, R.T.M., 1987. Kualitas dan Pencemaran Lingkungan. Fakultas Pascasarjana, Institut Pertanian Bogor: 92 hal.

US Environmental Protection Agency. 1973. Water Quality Criteria 1972, EPAR3-73-033-March 1973. p177

Wardoyo, S.T.H. 1982. Water Analysis Manual Tropical Aquatic Biology Program. Biotrop, SEAMEO. Bogor. p 81.

Wattayakorn, G. 1988, Nutrient Cycling in Estuarine. Paper presented in the Project on Research and its Application to Management of the Mangrove of Asia and Pasific, Ranong, Thailand. 